\title{
Physiological Quality of Salvia hispanica L. Seeds at Differents Paraquat Application Moments
}

\author{
Y. M. Lezcano Aquino ${ }^{1}$, L. Ayala Aguilera ${ }^{1}$, E. Añazco ${ }^{1}$, P. V. Peña Alvarenga ${ }^{1}$, M. J. González Vera ${ }^{1}$ \\ \& H. Sarubbi Orué ${ }^{2}$ \\ ${ }^{1}$ Laboratorio de Análisis de Calidad de Semillas, Área de Producción Agrícola, Facultad de Ciencias Agrarias, \\ Universidad Nacional de Asunción, San Lorenzo, Central, Paraguay \\ 2 Área de Protección Vegetal, Facultad de Ciencias Agrarias, Universidad Nacional de Asunción, San Lorenzo, \\ Central, Paraguay \\ Correspondence: Y. M. Lezcano Aquino, Facultad de Ciencias Agrarias, Universidad Nacional de Asunción, P.O. \\ Box 2160, San Lorenzo, Central, Paraguay. E-mail: ylezcano@agr.una.py; lab.semillas@agr.una.py
}

Received: May 5, 2019

Accepted: July 24, 2020

Online Published: August 15, 2020

doi:10.5539/jas.v12n9p252

URL: https://doi.org/10.5539/jas.v12n9p252

\begin{abstract}
Chía (Salvia hispanica L.) seed contains more oil and protein than other grains, has a high content of omega-3 linolenic acid, essential for human nutrition. Paraguay is currently among the five largest chía producer countries in the world, with 80000 ha planted in 2013. The experiments were carried out during the months of March and October of 2017, the field work was made in the district of Chore-San Pedro, Paraguay departament, and laboratory evaluations in the Seed Analysis and Quality Laboratory of Agrarian Sciences, National University of Asunción-Paraguay. The objective of this investigation was to determine the physiological quality effect on chia seeds with differents paraquat moments application. The variables study consisted in evaluate the seeds germinative power, calculate the vigor by measuring length of seedlings and accelerated aging, also estimate different harvest times yield. The randomized complete blocks design was used with 4 treatments with 4 repetitions. The obtained results were analyzed by ANOVA and the means were compared using the Tukey test at $5 \%$ probability. The Paraquat herbicide was applied as a desiccant to accelerate and standardize the chia harvest at different maturing times, called as early, middle and late. In all the analyzed variables it is shown that the early application obtained the best results concluding that the application of paraquat in early harvest favors the yield and the final quality of the seeds.
\end{abstract}

Keywords: chia, physiological quality, seeds, vigor, desiccant

\section{Introduction}

Salvia hispanica $\mathrm{L}$. is an annual herbaceous plant in the Lamiaceae family. It has as its likely center of origin the mountainous areas of western and central Mexico. It is known by several common names: "Spanish sage", "Spanish artemisa", "Mexican chía", "black chia" or simply "chia", the most used in the world (Beltrán-Orozco \& Romero, 2003).

Chia seeds are natural resources of plant origin with the highest fatty acid content known to date, with emphasis on alpha linolenic acid (omega 3 ) and linoleic acid (omega 6), which are essential fatty acids for humans. It is not able to perform biosynthesis and therefore must be provided by the diet (Mohd et al., 2012).

Paraguay is currently among the five largest chia producer countries in the world, with 80000 ha planted in 2 013, along with Argentina, Bolivia, Australia and Mexico, actualy being one of the best business opportunities in the agricultural sector, for primary growers as well the exporting companies (MAG, 2014). The commercial areas average yield for this crop is around 500-600 kg/ha, although up to $1260 \mathrm{~kg} / \mathrm{ha}$ has been achieved (Ayerza, 2005).

According to Busilacchi et al. (2013), nowadays is admitted that the development and economy of many Latin American countries and regions can be significantly improved with the cultivation and production of native species that are being revalued worldwide for their nutritious and healthy properties. Agriculture represents the main source of income for rural population of the region countries, especially those that still have a subsistence 
agriculture with practices adapted to the smallholding with a high dependence on imported inputs, the Salvia hispanica $\mathrm{L}$. is a cultivated specie of that group.

In the production of grains, one of the most important stages is the obtaining of high quality seeds, the most visible difference between chia seeds in terms of good and poor quality, is the color of the seeds, since their presence of yellow, yellowish, brownish and light brown seeds, are synonymous with vain, dead or undeveloped seeds. Also, these yellow-brown seeds are immature and contain less minerals, proteins, vitamins and omega-3 fatty acids. Good quality seeds are dark gray, brown, white or dark brown (Scalise, 2015)

An alternative for the producers, to minimize the quality seeds deterioration in the field or to anticipate the commercial areas production harvest, is the use of desiccant herbicides and the application of them is effectuated when most of the seeds are ripe, in order to promote a faster drying of plants and the uniformity maduration increase, which facilitates the harvest, obtaining less impurities quantity and better quality seeds (Inoue et al., 2003).

Gomes et al. (2003), point out that bipyridyl herbicides are considered very effective, because they are quickly absorbed by plants, but they are not translocated in enough quantities to destroy the roots. Baricco (2015), states that there are many different herbicides used as chemical desiccants, such as paraquat (contact) or glyphosate (systemic); however, there are conflicting opinions about whether one or the other type of product could generate a quality seeds decrease obtained (germinative power, first reading, weight of a thousand seeds, abnormal seedlings and dead seeds). The same author mentions that there is no unanimous agreement regarding the application time of the desiccant, he also mentions that the stage in which this practice is performed is essential for the seed quality obtained and has an important relationship with the possibility of product adverse effects that are used as desiccant on the seed.

Malaspina et al. (2012), mention as a classic contact herbicide example, the paraquat, inhibitor of the photosynthetic system, which drastically reduces the water content of the plants green biomass. The mechanism of action is through the blocking of electrons from photosynthesis, preventing the reduction of NADP + to NADPH 2. Thereby, the accumulation of electrons and free radicals occurs in the chloroplast, causing severe damage to cellular metabolism, such as structural damage to DNA, proteins, lipids and pigments (Benavides et al., 2000). These radicals are unstable and suffer from auto-oxidation, producing superoxide radicals, hydroxyl and oxygen singly, which, in turn, are reactive to the lipids of cell membranes, promoting their peroxidation. With the membrane's degradation, the emptying of the cell juice and tissue death is originated (Vargas, 1999).

Kappes et al. (2009), highlights that some important aspects should be considered when desiccants are used, since the physiological quality of seeds and productivity can be affected. The objective of this work was to determine the effect of differents paraquat times application on the physiological quality of chía seeds, while the specific objectives consisted in calculate the density of seeds, evaluate the germinative power of the seeds, calculate the vigor through the seedling length analysis and electrical conductivity, and estimate the yield at different harvest times.

\section{Materials and Methods}

The field experiment was conducted in the District of Chore, San Pedro departament, whose coordinates are latitude $24^{\circ} 12^{\prime}$ south and longitude $56^{\circ} 34^{\prime}$ west, with elevation of $227 \mathrm{~m}$ at sea level. Laboratory's variables were evaluated in the Seed Analysis and Quality Laboratory in the Agrarian Sciences Faculty of the Asunción National University (FCA-UNA), located at $11 \mathrm{~km}$ of Asunción, Central Department, Eastern Region, Paraguay, which geographic coordinates are latitude $25^{\circ} 19^{\prime} 35^{\prime \prime}$ south and longitude 57 $31^{\prime} 13^{\prime \prime}$ west. The field and laboratory experiments were carried out during the months of March to October 2017.

The experiment consisted in the application of the paraquat herbicide as a desiccant, in order to accelerate and standardize the harvest of chia seeds, at different maturation times, called as early, middle and late. A coastal sprayer was used with a 5 liters capacity with a flat fan spray nozzle for the application of the herbicide. The randomized complete blocks design was used with 4 treatments with 4 repetitions, where: T0 natural drying: control, naturally dried plant without application of paraquat; T1 early application: application of paraquat desiccant, 21 days before harvest maturity; T2 middle application: paraquat desiccant application, 14 days before harvest maturity; T3 late application: application of desiccant paraquat, 7 days before harvest maturity.

The treatments and repetitions were arranged in rows with a total of 16 experimental units in an area of $10 \mathrm{~m}^{2}(5$ $\mathrm{m} \times 2 \mathrm{~m}$ ) per experimental unit and a total area of $160 \mathrm{~m}^{2}$, the dose of the herbicide was $2.5 \mathrm{l} / \mathrm{ha}$. A seeding density of $0.45 \mathrm{~m}$ between rows and 20 plants $/ \mathrm{m}$ was used, completing a total of 5 rows per experimental unit. 
Direct sowing system was carried out, using chia seeds (Salvia hispanica L.) of black tegument, obtained from local trade, from the 2016 harvest. The predominant soils in the area are classified as Typic Paleudults (López et al., 1995), sandstone derivatives with a sandy surface texture and accumulation of subsurface clay (horizon B iluvial). The fertility level is low and acidic $\mathrm{pH}$, the color ranges from yellowish red to brown gray.

The germination percentage evaluation was conducted according to indications proposed in the International Seed Testing Association (ISTA, 2017; Stefanelo et al., 2015), for which 4 replicates of 100 seeds per treatment were used, they were seeded on absorbent paper previously sterilized and moistened with distilled water in "gerbox" type plates, which were introduced in a germinator at $20-30{ }^{\circ} \mathrm{C}$ for 7 days, once the time elapsed, the count of the considered normal seedlings was made, being those that contained their essential structures.

The root length analysis for which 20 seeds were seeded in "gerbox" plates on germitest paper substrate, moistened with distilled water and placed inside a germinator at $25^{\circ} \mathrm{C}$ with constant light, after 7 days 10 seedlings of each repetition considered normal were counted and the length of the root was measured with a centimetric ruler, the results were expressed in centimeters (Krzyzanowski, 1999).

For electrical conductivity, four seeds sub-samples were used for each treatment, 10 grams seeds were immersed in $100 \mathrm{ml}$ of deionized water and this samples were kept in a germination room with a controlled temperature of $25{ }^{\circ} \mathrm{C}$. The evaluation was carried out in intervals of one hour, up to a maximum of 24 hours, in this investigation only the hour 24 evaluation is shown, because it has been proved by a pretest that this is the time in which it releases the maximum amount of electrolytes, could be observed that after 20 hours it began to stabilize. To obtain the blank reading of the water, the initial content of electrical conductivity was measured. The readings were made using a device called a conductivity meter (model ORION STAR A212). The result obtained in the conductivity minus the blank test was divided by the mass of each seed repeat and was expressed in $\mu \mathrm{S} \mathrm{cm}^{-1} \mathrm{~g}^{-1}$. The average values obtained for the reading in each batch were expressed in $\mu \mathrm{S} \mathrm{cm}^{-1} \mathrm{~g}^{-1}$ (Krzyzanowski, 1999).

Yield was evaluated by harvest, which was executed manually, cutting the plants that later were stacked and transported under a warehouse and then proceeded to thresh them with help of an electric thresher. The threshed seeds were homogenized with help of shakers and finally they were conditioned in paper bags, correctly identified. Subsequently, the samples were weighed on a precision scale of two decimals, the result was expressed in $\mathrm{kg} / \mathrm{ha}$.

\subsection{Experimental Design}

The results were obtained through the analysis of ANOVA with the help of the InfoStat program (Di Rienzo et al., 2011). The average was compared using the Tukey test at $5 \%$ probability and the results were presented by tables using the Microsoft Excel program.

\section{Results and Discussion}

The data obtained for the chia seeds yield variable $(\mathrm{kg} / \mathrm{ha})$ var. common (Table 1$)$, showed that there are significant statistical differences between the different treatments. It is shown that the $\mathrm{T} 1$ of early application obtained the best result with $693.38 \mathrm{~kg} / \mathrm{ha}$, surpassing the average figure of our country cited by (Ayala, 2013).

Table 1. Germination test (G) (\%); root length (RL) (cm), electrical conductivity (EC) $\left(\mu \mathrm{S} \mathrm{cm}^{-1} \mathrm{~g}^{-1}\right)$ and yield $(\mathrm{Kg} / \mathrm{ha})$ of chía var. common from dryed plants with paraquat, at three different moments application and one control. Chore, San Pedro, PY, 2017

\begin{tabular}{lllll}
\hline Treatments & $\mathrm{G}(\%)$ & $\mathrm{RL}(\mathrm{cm})$ & $\mathrm{EC}\left(\mu \mathrm{S} \mathrm{cm}^{-1} \mathrm{~g}^{-1}\right)$ & Yield $(\mathrm{Kg} / \mathrm{ha})$ \\
\hline T0 Naturally dryed & $60 \mathrm{bc}$ & $28.37 \mathrm{~b}$ & $100.80 \mathrm{~b}$ & $130.7 \mathrm{~b}$ \\
T1 Early application & $86 \mathrm{a}$ & $44.82 \mathrm{a}$ & $51.82 \mathrm{a}$ & $693.38 \mathrm{a}$ \\
T2 Middle application & $74 \mathrm{ab}$ & $44.52 \mathrm{ab}$ & $73.09 \mathrm{a}$ & $204.23 \mathrm{~b}$ \\
T3 Late application & $47 \mathrm{c}$ & $43.65 \mathrm{~b}$ & $106.80 \mathrm{~b}$ & $146.43 \mathrm{~b}$ \\
\hline Media & 67 & 40.34 & 83.12 & 293.68 \\
CV $(\%)$ & 16 & 10.48 & 10.89 & 40.07 \\
\hline
\end{tabular}

Note. Average followed by the same letters in the columns, do not differ statistically by Tukey's test, at $5 \%$ probability. $\mathrm{CV}$ : coefficient of variation. $\mathrm{RL}=$ root length; $\mathrm{G}=$ germination test; $\mathrm{EC}=$ electrical conductivity.

The plants desiccants application influences the final yield obtained depending on the time of desiccation. Between the physiological and commercial maturity, the dominant physiological process will be the loss of 
humidity of the grain, conditioned by genotypic and environmental characteristics (Satorre et al., 2003). At this point the desiccant herbicide use causes a shortening of the period between physiological maturation and harvest.

The chia cultivation of should be established in areas that at least show a rainfall per week, or an well distributed average of 800 to $900 \mathrm{~mm}$ per year, temperatures not higher than $33{ }^{\circ} \mathrm{C}$, since environmental conditions can affect the amount, or seeds quality in development, regard to the nutritional values or to the content of certain elements such as oil and fats (Manzaneda, 2015). The results obtained from the performance depending on the desiccant herbicide application time, evidence that drying at early maturation stage allows to obtain a better performance, later applications may not be effective since as the plant matures tends to lose the fruits located at the bottom of the plant.

The data obtained in the germination test $(\%)$ and root length $(\mathrm{cm})($ Table 1), indicate significant statistical differences in both variables. For the germination variable, the highest value was obtained by the T1 of early application, with $86 \%$ of normal seedlings without differing statistically from the T2 middle application, with $74 \%$. The lowest values were obtained in the control and T3 late application. Likewise, for the root length variable, the best result was obtained by the T1 early application, with $44.82 \mathrm{~cm}$, followed by the middle application, with $44.52 \mathrm{~cm}$ indicate no statistical difference among them.

Climate changes accompanied by high precipitation rates in the maturation and pre-harvest phase can cause losses in physical and physiological quality as in the seed health, besides the application of desiccants in pre-harvest contributes to reduction of seeds exposure to adverse climatic conditions and reduce the possibility of losses in germination and vigor (Daltro et al., 2010).

The result obtained by the germination test reveals that the early application batch is the only one that reaches the minimum germination percentage required for seed commercialization in Paraguay (SENAVE, 2014) which requires $80 \%$ for certified and/or inspected seeds. The percentages obtained with the middle and late application are below the minimum parameters required.

The meaning of vigor is driving force or growth energy during the germination process, to stand out the seeds that will produce seedlings with longer roots than those originated from the less favored seeds of the same batch (Marcos-Filho, 2015). The same author affirms that the vigor manifestation depends on the environment conditions, and in this case it is observed that the paraquat herbicide had no negative effect on the seeds vigor, however, the time elapsed between physiological maturity and the harvest time did affect the result, presenting shorter roots in the control than the average.

The field seeds deterioration at the harvest time is particularly risky in Paraguay due to the precipitation that normally occurs during this period, these conditions can delay the harvest of the crop hat these conditions significantly reduce the germinative potential and the seeds vigor, this effect is with its consequent negative impact on the seed's quality (Martínez, 2011). Similarly, Minuzzi et al. (2007), points out t observed in the control and the applied treatments after the first application, since they have a lower germination percentage and vigor.

In the table 1, column EC, we can see that better results were obtained with treatments 1 (early application) and 2 (average application), where a lowest amount of leached electrolytes is observed, proving to be the most vigorous, demonstrating a similar behavior to that obtained in length of seedlings. Vanzolini and Nakagawa (2005) state that seeds with low vigor require a greater amount of nutrients, such as sugars, amino acids and fatty acids, which are essential for the restoration of cell membranes and the reactivation of metabolism during the process of imbibition, for this reason, those seeds with less physiological potential tend to present a greater ion leaching.

Kappes et al. (2009), analyzing the soybean seeds physiological potential, M-Soy 8866 variety, dried with diquat and paraquat in Santa Carmem location, Mato Grosso north, in 2006/2007 agricultural year, verified the dried lots with paraquat, compared to the control batch without desiccant, presented better performance in some of the quality tests used.

Radke et al. (2018) concluded that the electric conductivity tests in the combination of 50 seeds with $50 \mathrm{ml}$ of water during 24 hours of imbibition were efficient to stratify lots of chia seeds with different vigor levels, they obtained values with ranges from 575.4 to $759.9 \mu \mathrm{S} \mathrm{m}^{-1} \mathrm{~g}^{-1}$ (EC), values far from those found in this work, in which $100 \mathrm{ml}$ of water was used for imbibition, which is explained by Torres and Pereira (2010) who work with arugula seeds, claim that the leachate values decreased as the volume of water increases, a fact attributed to the dilution caused by the increase in the amount of water used to imbibe the seeds. 
Kappes et al. (2012) mention that, a general way the delay in drying, of the application provided a vigor reduction, probably due the longer time the seeds are in the field during the physiological maturation process. The same authors affirm that in the pre-harvest season, they are exposed to adverse conditions of humidity and temperature.

The seeds quality decreases from the physiological maturity depending on the climatic conditions, an alternative to minimize the deterioration of the seed's quality in the field or to anticipate the harvest in commercial areas of production is the use of desiccant herbicides (Malaspina et al., 2012).

\section{Conclusions}

The application moment of paraquat in plants influences the final yield depending on the time desiccant application.

The desiccation with paraquat in pre-harvest of chía must be done at the physiological maturation plants time to favor a higher yield and decrease the natural shelling.

The chía seeds germination and vigor are positively influenced when applying paraquat at the physiological maturation plant time.

\section{References}

Ayala, L. (2013). Tecnología de Semillas, siembra e instalación del cultivo de Salvia hispánica. Asunción, PY. Retrieved from http://www.paraguayorganico.org.py/wp-content/uploads/2013/07/1-Semillassiembra-e-inst alaci\%C3\%B3n-del-cultivo-de-Ch\%C3\%ADa.-Prof.Dr_.L\%C3\%ADder-Ayala-Aguilera.pdf

Ayerza, R. Jr., \& Coates, W. (2005). Chía. Rediscovering a Forgotten Crop of the Aztecs (1st ed., p. 197). The University of Arizona Press, Tucson, USA.

Baricco, I. (2015). Efecto de la aplicación de desecantes sobre la calidad de semillas de Garbanzo. Retrieved from https://rdu.unc.edu.ar/bitstream/handle/11086/2044/Baricco\%2c\%20Juan\%20Ignacio\%20-Efecto\%20 de $\% 201$ a $\% 20$ aplicaci\%C3\%B3n\%20de $\% 20$ desecantes.pdf? sequence $=1 \&$ isAllowed $=\mathrm{y}$

Beltrán-Orozco, B., \& Romero, M. R. (2003). La chía, alimento milenario. Revista Industria Alimentaria, 25(5), 20-29.

Benavide, S. M., Gallego, S. M., Comba, M. E., \& Tomaro, M. L. (2000). Relationship between polyamines and paraquat toxicity in sunflower leaf discs. Plant Growth Regulation, 31(3), 215-224. https://doi.org/10.1023/ A:1006316926002

Busilacchi, H., Quiroga, M., Bueno, M., Di Sapio, O., Flores, V., \& Severin, C. (2013). Evaluación de Salvia hispánica L. cultivada en el sur de Santa Fe (República Argentina). Cultivos Tropicales, 34(4), 55-59.

Cabrera, D. (2017). Sistema de producción agroecológico en el cultivo de la Chía. San Lorenzo, PY. Retrieved from http://www.paraguayorganico.org.py/wp-content/uploads/2013/07/2-Experiencia-demanejo-CHIA-Da vid-Cabrera.pdf

CADPSA (Compañía Agrotabacalera del Paraguay S.A.). (2010). Guía práctica sobre la producción de tabaco Burley (p. 38). Choré, PY.

Daltro, E. M. F., Albuquerque, M. C. De F., Neto, J. de B. F., Guimarães, S. C., Gazziero, D. L. P., \& Henning, A. A. (2010). Aplicação de desecantes em précolheita: Efeito na qualidade fisiológica de sementes de soja. Revista Brasileira de Sementes, 32(01), 111-122. https://doi.org/10.1590/S0101-31222010000100013

Di Rienzo, J. A., Casanoves, F., Balzarini, M. G., Gonzalez, L., Tablada, M., \& Robledo, C. W. (2011). InfoStat Versión 2011. Grupo InfoStat, FCA, Universidad Nacional de Córdoba, Argentina.

Gomes, J. C., Soares, L. F., Pereira, C. A. dos S., \& Jham, G. N. (2003). Efeito do desecante paraquat na qualidade da fração lipídica da soja. Ciência e Agrotecnologia, 27(01), 178-184. https://doi.org/10.1590/ S1413-70542003000100022

Inoue, M. H., Orivaldo, M. J., Braccini, A. L., Oliveira Júnior, R. S., Ávila, M. R., \& Constantin, J. (2003). Rendimento de grãos e qualidade de sementes de soja após a aplicação de herbicidas desecantes. Ciencia Rural, 33(04), 769-770. https://doi.org/10.1590/S0103-84782003000400030

ISTA (International Seed Testing Association). (2017). International rules for seed testing (p. 375). Bassersdorf.

Kappes, C., Arf, O., Ferreira, J. P., Portugal, J. R., Alcalde, A. M., \& Arf, M. V. (2012). Qualidade fisiológica de sementes e crescimento de plântulas de feijoeiro, em função de aplicações de paraquat em pré-colheita. Pesquisa Agropecuária Tropical, 42(1), 9-18. https://doi.org/10.1590/S1983-40632012000100002 
Kappes, C., Carvalho, M., Yamashita, O., \& Silva, J. (2009). Influência do nitrogênio no desempenho produtivo do milho cultivado na segunda safra em sucessão à soja. Pesquisa Agropecuária Tropical, 39(3), 251-259.

Krzyzanowski, F. C., Vieira, D. R., \& França Neto, J. B. (1999). Vigor de sementes: Conceitos e testes (p. 218). Londrina, Paraná, Brasil: Associação Brasileira de Tecnologia de Sementes-ABRATES.

López, O., González, E., Llamas, A., Molinas, A., Franco, E., García, S., \& Ríos, E. (1995). Estudio de reconocimiento de suelos, capacidad de uso de la tierra y propuesta de ordenamiento territorial preliminar de la región oriental del Paraguay (pp. 126-246). Asunción, PY.

MAG (Ministerio de Agricultura y Ganadería). (2014). Paraguay encabeza la lista de los 5 países productores de Chía más grandes del mundo. Asunción, Paraguay. Retrieved from http://www2.mag.gov.py/index-news. php?pag=not_ver.php\&tit=Boletín\%20informativo...\&idx=937611\#.WQT_kYg1_b0

Malaspina, I., Lazarini, E., Silva, W., Marcandalli, L. H., \& Alvarez, F. (2012). Épocas de aplicación de desecantes en el cultivo de soja: tenor de agua y productividad. Revista Ciência Agronômica, 43(4), 749-756. https://doi.org/10.1590/S1806-66902012000400017

Manzaneda, F. (2015). Evaluación de la producción de dos variedades de Chía (Salvia hispánica L.), en dos densidades de siembra. La Paz, Bolivia. Retrieved from http://www.revistasbolivianas.org.bo/scielo. php?pid $=$ S010203042015000100003\&script $=$ sci_arttext\&tlng $=$ es

Marcos-Filho, J. (2015). Fisiologia de sementes de plantas cultivadas (pp. 563-576). Londrina-PR: Associação Brasileira de Tecnologia de Sementes.

Martínez, J., Ayala, L., \& Ayala, M. (2011). Efecto de los desecantes Paraquat y Glufosinato de amonio en el rendimiento y calidad física y fisiológica de semillas de soja (Glycine max L. Merril). Investigación Agraria, 13(1), 33-40.

Minuzzi, A., Mora, F., Sedrez, M. A., De Lucca, A., \& Scapi, C. A. (2007). Características fisiológicas, contenido de aceite y proteína en genotipos de soya, evaluadas en diferentes sitios y épocas de cosecha, Brasil. Agricultura Técnica, 67(4), 353-36. https://doi.org/10.4067/S0365-28072007000400003

Mohd Ali, N., Yeap, S. K., Ho, W. Y., Beh, B. K., Tan, S. W., \& Tan, S. G. (2012). The promising future of chía, Salvia hispánica L. Journal of Biomedicine \& Biotechnology, 2012, Article ID 171956. https://doi.org/ $10.1155 / 2012 / 171956$

Radke, A. K., Maass, D. W., Pieper, M. S., Xavier, F. M., Martins, A. B. N., Vergara, R. O., ... Meneghello, G. E. (2018). Electrical Conductivity Test to Evaluate the Physiological Quality of Salvia hispanica L. Seeds. Journal of Agricultural Science, 10(3), 377. https://doi.org/10.5539/jas.v10n3p377

Satorre, E., Benech, A. R., Slafer, G., De La Fuente, E., Miralles, D., Otegui, M., \& Savin, R. (2003). Producción de granos. Bases funcionales para su manejo (1st ed., p. 783). Buenos Aires, AR: Facultad de Agronomia UBA.

Scalise, J. (2015). Caracterización y diagnóstico de la cadena de valor de la chía en Argentina. Buenos Aires, AR. Retrieved from http://www.fao.org/family-farming/detail/es/c/359154

SENAVE (Servicio Nacional de Sanidad y Calidad Vegetal y de Semillas). (2014). Normas especificas para la producción y comercialización de semillas certificadas y fiscalizadas (p. 397). Asunción, PY.

Stefanelo, R., Salles, N., Abbad, M., \& Boucinha, B. (2015). Resposta fisiológica de sementes de chía (Salvia hispánica Lamiales: Lamiaceae) ao estresse salino. Biotemas, 28(4), 35-39. https://doi.org/10.5007/ 2175-7925.2015v28n4p35

Torres, S. B., \& Pereira, R. A. (2010). Condutividade elétrica em sementes de rúcula. Revista Brasileira de Sementes, 32(4), 58-70. https://doi.org/10.1590/S0101-31222010000400007

Vanzolini, S., \& Nakagawa, J. (2005). Teste de condutividade elétrica em sementes de amendoim. Revista Brasileira de Sementes, 27(2), 151-158. https://doi.org/10.1590/S0101-31222005000200022

Vargas, L. (1999). Resistência de plantas daninhas a herbicidas (p. 31). Viçosa: Jard Produções Gráficas. 


\section{Copyrights}

Copyright for this article is retained by the author(s), with first publication rights granted to the journal.

This is an open-access article distributed under the terms and conditions of the Creative Commons Attribution license (http://creativecommons.org/licenses/by/4.0/). 